\title{
Wacana Homo Nationalis dalam Iklan Minuman NutriSari Heritage
}

\author{
Adek Risma Dedees \\ Mahasiswa Kajian Budaya dan Media Sekolah \\ Pascasarjana Universitas Gadjah Mada Yogyakarta
}

\begin{abstract}
Discourse of homo nationalis or 'nationality' at NutriSari Heritage drinking ads is fulled by construction of 'national identity' as a part of Indonesian 'nation'. This ads explains refraction or 'pseudoisation' of ethnicity of representation on discourse of homo nationalis as implication because of be valued majority or fulled by highest valued (luhung). The refraction might happened because of existence stereotyping toward ethnicity of nation certain. Stereotyping is produced, reproducted, guarded, keeped, and even preserved in multiple discourses, in this case at drinking advertisement. Method of this research is qualitative-interpretative within used critical discourse analysis approach. This research use Ruth Wodak critical discourse analysis modal. It is used for interpretating and elaborating homo nationalis discourse in naration constructing of 'nationhood'
\end{abstract}

Keywords: homo nationalis, nation, ethnicity, advertisement/ads, stereotyping

\begin{abstract}
Abstrak
Pewacanaan homo nationalis atau 'kebangsaan' dalam iklan minuman NutriSari Heritage penuh akan konstruksi 'identitas kebangsaan' sebagai bagian dari suatu 'bangsa' Indonesia. Iklan ini memperlihatkan adanya bias-bias atau ke-semu-an representasi etnisitas/suku bangsa dalam mewacanakan homo nationalis sebagai implikasi karena 'dianggap' mayoritas atau dianggap 'luhung'. Bias-bias ini, agaknya, terjadi dikarenakan masih adanya pelabelan tertentu (stereotype) terhadap etnisitas/suku bangsa tertentu. Pelabelan ini diproduksi, direproduksi, dijaga, dirawat, dan bahkan dilestarikan dalam berbagai pewacanaan. Metode yang digunakan dalam penelitian ini adalah metode kualitatif-interpretatif dengan menggunakan pendekatan analisis kritis. Model analisis yang digunakan ialah perspektif wacana kritis ala Ruth Wodak dkk. Analisis wacana kritis digunakan untuk menginterpretasi dan mengelaborasi wacana homo nationalis dalam pembentukan narasi 'kebangsaan'.
\end{abstract}

Kata Kunci: wacana, homo nationalis, bangsa, etnis, iklan 


\section{Latar Belakang}

Bhinneka Tunggal Ika. Unity in Diversity. Satu kesatuan dalam keanekaragaman. Ungkapan ini mewakili keberadaan Indonesia sebagai nationstate dengan beragam kepercayaan/ agama, etnisitas/ras, gender, kelas sosial, dan juga golongan usia. Bhinneka Tunggal Ika ini mengusung ideologi tentang pola hubungan kemasyarakatan dan budaya di nusantara. Seperti yang diketahui, keanekaragaman selalu dijaga dan dilestarikan, namun kesatuan juga selalu dikampanyekan. Keanekaragaman sebagai kondisi 'nyata' bangsa Indonesia, serta kesatuan menjadi semacam harapan guna mewujudkan kehidupan yang damai sebagai cita-cita sekaligus 'tanggung jawab' hidup berbangsa dan bernegara di Indonesia -'cita-cita nan mulia'. Noviani (2012:13) menegaskan, perbedaan budaya di Indonesia selalu berkaitan erat dengan proses pembentukan 'keharmonisasian atau kerukunan bangsa'. Sehingga, adalah menjadi semacam 'keniscayaan', secara kultural ideologis, Indonesia -sudah selaiknya- mengakui multikulturalisme, sebagai implikasi dari Bhinneka Tunggal Ika.

Kesadaran akan 'pentingnya' mengelola perbedaan dan kesadaran akan 'pentingnya' bersatu dalam perbedaan itu, terjewantah dalam frase satu 'bangsa'. Frase ini berdaya magnet kuat guna menyatukan perbedaan dari berbagai penjuru tanah air di bawah satu payung bernama Garuda Pancasila. Kuatnya daya tarik 'bangsa', seperti yang didefinisikan oleh Anderson (2008: 8), bangsa sebagai "an imagined political community, adalah sesuatu yang terbayang karena para anggota bangsa terkecil sekali pun tidak bakal tahu dan takkan kenal sebagian besar anggota lain, tidak akan bertatap muka dengan mereka itu, bahkan mungkin tidak pula pernah mendengar tentang mereka". Namun, toh di benak setiap orang yang menjadi anggota bangsa itu hidup sebuah bayangan tentang kebersamaan mereka. 'Bangsa' dibayangkan sebagai komunitas inilah, sebab, tak peduli akan ketidakadilan yang ada dan penghisapan yang mungkin tak terhapuskan dalam setiap bangsa, bangsa itu sendiri selalu dipahami sebagai kesetiakawanan yang masuk mendalam dan melebar-mendatar. Pada akhirnya, selama dua abad terakhir, rasa persaudaraan inilah yang memungkinkan begitu banyak orang, jutaan jumlahnya, bersedia jangankan meleyapkan nyawa orang lain merenggut nyawa sendiri pun rela demi membayangkan tentang yang 'terbatas' itu, (Anderson, 2008: 11). Bayangan kebersamaan ini kemudian memosisikan 'bangsa' erat kaitannya dengan 'harkat', 'martabat', dan 'derajat' secara sosio-politik serta kultural, dalam 'diri' individu serta kelompok.

Media kerap menampilkan 'bangsa' dalam beragam 'kemasan' dan berupa 'paket-paket'. Menghadirkan atributatribut kebudayaan dan etnisitas adalah salah satu bentuk pilihannya. Iklan 
merupakan satu dari sekian banyak wahana yang menampilkan 'bangsa' serta atributnya sebagai salah satu cara menggaet calon konsumen. Kehadiran 'bangsa' dalam iklan tidak semata-mata sebagai atribut, 'penghias' serta 'penarik' selera. Akan tetapi, iklan juga menjadi sarana dalam pembentukan 'bangsa' melalui -sebagian- citra-citra yang dihadirkan dalam iklan sebagai konstruksi dan representasi nation-state Indonesia. Goldman (1992: 8) menjelaskan, teori kritik yang dipakai dalam iklan tidak semata-mata studi akan iklan, tetapi sebagai teori analisis dalam melihat hubungan antara (iklan) bentuk komoditas dan proses pembentukan atau reproduksi ideologi di dalamnya. Noviani (2012: 14) mengatakan.

Advertising images and narratives are intricately linked to larger and broader socio-political arrangements at certain historical moments in a given society.

Frith dan Barbara (2003: 38) menjelaskan, akhirnya iklan (dan advertisers) juga menjadi 'kreator' ulung yang menggemakan pesan melalui perhatian tentang perbedaan dimensi dari satu pasar ke pasar lainnya- seperti waktu, konteks, kuasa, jarak, binary individual versus komunal, maskulinitas versus femininitas, serta budaya yang mana gagasan-gagasan ini merembes dan terefleksi dalam institusi sosial sebagai produk budaya.

Iklan sebagai produk dan praktik budaya tidak terlepas dari kepentingan- kepentingan serta ideologi dari pembuat iklan. Iklan tidaklah 'stabil' sebagai sebuah iklan. Dines dan Humaz (dalam Noviani, 2012: 16) mengatakan.

... that advertising images are historical documents, which articulate dominant values, political ideologies and social developments as well as novelties of a given era.

Iklan yang menampilkan citra dan cerita tentang 'bangsa' ketika berjualan untuk meraup sebanyak mungkin keuntungan -sebagai salah satu motor penggerak ekonomi sekaligus media penjaga kontinuitas kapitalisme- sarat akan muatan budaya, tradisi, serta local wisdom di dalamnya. Brierley (1995: 191192) mengungkapkan.

This (goods as the "vehicles of cultural meanings") involves the use of symbols, myths and metaphors to add meanings to goods and add to the meanings that the advertiser wants to convey. This means surveying the world for the culturally constituted objects, persons, contexts and motifs that make the sought after cultural meanings live in the advertisement.

Jelas terlihat bagaimana posisi iklan tidak sekadar berfungsi untuk menjual produk, lebih dari itu iklan menjadi sarana sebagai pewacanaan untuk membayangkan, merawat, menegosiasikan, bahkan melakukan pembias-an pada etnisitas tertentu dalam koridor 'kebangsaan'.

Berdasarkan itulah makalah ini ditulis guna melihat wacana 'bangsa' (dalam hal ini memakai term homo nationalis) di dalam iklan minuman 
NutriSari Heirtage. Metode yang digunakan dalam penelitian ini adalah metode kualitatif-interpretatif dengan menggunakan pendekatan analisis kritis. Model analisis yang digunakan ialah perspektif wacana kritis ala Ruth Wodak dkk. Analisis wacana kritis digunakan untuk menginterpretasi dan mengelaborasi wacana homo nationalis sebagai pembentukan narasi kebangsaan dalam iklan minuman NutriSari Heritage baik melalui bahasa, teks, visual, audio, gerakan tubuh (body language) maupun ideologi, kekuasaan, serta konteks sejarah yang dibangun.

\section{Iklan NutriSari Heritage}

NutriSari adalah nama merek produk dagang asli Indonesia yang dimiliki oleh perusahaan Nutrifood Indonesia. Nutrifood, didirikan pada bulan Februari 1979, merupakan perusahaan swasta nasional yang bergerak dalam bidang industri makanan dan minuman, khususnya makanan dan minuman yang memberikan manfaat untuk kesegaran, kesehatan, dan penampilan. Produk NutriSari umumnya dijual dalam bentuk jus dalam kemasan 11 gram hingga 200 gram (wikipediaindonesia.com/NutriSari).

Iklan minuman NutriSari Heritage ini menggandeng Joshua, penyanyi cilik yang beranjak dewasa, sebagai endorser utama. Calon konsumen produk ini adalah anakanak Indonesia dan masyarakat secara luas dari berbagai usia, jenis kelamin, kelas sosial, serta budaya. Iklan ini berdurasi 1 (satu) menit dan beredar di media massa elektronik pada kurun waktu 2011.

Iklan minuman NutriSari Heritage ini bercerita tentang kekayaan budaya dan alam Indonesia. Iklan ini menampilkan budaya dari lima etnis/suku bangsa di nusantara; Papua, Ambon, Jawa, Bali, dan Betawi. Kelima etnis/suku bangsa ini dihadirkan dengan khas kekayaan budaya dan tanah masing-masing. Ada yang menampilkan tarian tradisional, menampilkan permainan daerah, memakai pakaian daerah, memperkenalkan makanan dan minuman daerah, serta ritual-ritual daerah. Diversity yang dihadirkan ini, agaknya, menjadi penopang untuk menjual produk minuman NutriSari dengan versi heritage.

\section{Iklan sebagai Institusi Ekonomi dan Sosial}

Iklan yang hadir di tengah-tengah masyarakat pada umumnya bertujuan menarik minat calon pembeli untuk mengonsumsi (membeli) produk yang ditawarkan. Iklan hadir sebagai penyampai pesan dari produsen kepada calon konsumen. Kehadiran iklan berkaitan erat dengan market dan akumulasi profit dari produsen. Tampilan iklan dapat berbagai rupa; visual, audio, teks, atau gabungan ketiganya. Iklan muncul ke masyarakat baik dalam media cetak maupun media elektronik. Di media 
elektronik kehadiran iklan cenderung sebentar, biasanya hanya dalam hitungan detik hingga menit, seperti di TV, radio, dan beberapa di internet. Sementara di media cetak, kehadiran iklan dibatasi oleh space dan waktu yang tersedia. 'Grammar' iklan yang hanya hadir sebentar inilah, menuntut para pengiklan dalam mengemas produk yang diiklankan hingga mampu menarik minat calon konsumen. Moriarty dkk (2012: 520) menjelaskan:

Promotional planners develop their ideas-in fact, a Big Idea is just as important for sales promotion as it is for advertising. In many cases, the promotion is part of a bigger integrated marketing communication (IMC) plan, and one of the requirements is that the promotion's Big Idea should support the campaign's creative idea.

Akan tetapi, kehadiran iklan tidak sekadar sebagai institusi ekonomi yakni sarana menjual produk dan akumulasi profit. Iklan yang tersebar juga sebagai institusi sosial, teks budaya yang ideologis. Artinya, iklan sarat akan pertarungan, mengonstruksi, serta mensirkulasi makna, tarik menarik berbagai kepentingan, serta pewacanaan berbagai hal dalam 'realita' sosial. Noviani (2012: 16) mengatakan.

Advertising tends to weave of the selling product and social arrangements as well as social hierarchy in a given society and time period.

Iklan dalam masyarakat kapitalis tidak sekedar menjual produk yang berhubungan dengan materil, lebih dari itu, iklan menurut Raymond Williams (dalam Piller, 2001: 156) mencapai sukses dengan menyertakan pengetahuan sosial dan nilai-nilai personal. Pendapat ini juga diketengahkan oleh O'Barr, Goldman, \& Papson (dalam Piller, 2001: 156)

Other theorists are equally adamant that advertising does ideological work which but tresses a particulard istribution of power in society by representing model identities and idealized images, and by reflecting and constructing social relationships.

Oleh karena itu, iklan hadir tidak sesederhana yang dibayangkan dalam kehidupan sehari-hari. Lebih dari itu, iklan dan masyarakat berhubungan paralel seperti dua jalan raya. Agaknya, iklan merupakan representasi masyarakat, tetapi pada waktu yang sama, masyarakat juga direkonstruksi atau direproduksi oleh iklan.

Sistem referensi iklan melibatkan dua hal, yaitu sistem referen dan sistem produk. Sistem referen cenderung diambil dari nilai-nilai sosial kemasyarakatan yang ada. Sistem yang diambil ini kemudian dilekatkan ke dalam produk yang akan dijual. 'Memanipulasi' yang dilakukan ini mengakibatkan iklan 'kaya' akan nilainilai sosial baik dari budaya maupun dari agama. 'Kekayaan' akan nilai-nilai sosial ini tidak semata-mata 'melekat' tetap dalam iklan. Akan tetapi, ini merupakan proses pembentukan commodity sign oleh iklan. Goldman (1992: 21-23) menerangkan ada tiga elemen dalam 
proses commodity sign, yaitu abstraction sebagai pemisahan use value dan exchange value; equivalence sebagai kualitas objek yang dipisahkan dari konteks sosial dapat ditransfer pada objek apapun; dan reification sebagai transformasi nilai dan relasi sosial ke dalam objek atau produk.

\section{Wacana Homo Nationalis dalam Banyak Wajah}

Martin Heidegger (dalam Anderson, 2008: 8) menjelaskan dalam bahasa manajemen modern bahwa bangsa adalah proyek untuk dikerjakan, diolah, sehingga bangsa menjadi suatu mode of existence. Bangsa menjadi suatu proyek ke depan dan sekaligus ke belakang. Karena itu tidak pernah bisa dikatakan suatu bangsa "lahir", namun bangsa itu "hadir" dalam proses "formasi" sebagai "historical being" . "Historical" di sini bukan masa lalu akan tetapi mencakup masa depan dengan menggenggam kuat kekinian sambil memproyeksikan dirinya ke masa lalu. Dengan begitu warisan menjadi penting, namun bukan semata-mata itulah warisan, akan tetapi warisan yang secara efektif menentukan relevansi kekinian. Sementara 'bangsa' yang dibayangkan oleh Anderson (2008: 10) sebagai sesuatu yang pada hakikatnya bersifat terbatas secara inheren (sekaligus berkedaulatan) karena bahkan bangsa-bangsa paling besar pun, yang anggotanya mungkin semilyar manusia, memiliki garis-garis perbatasan yang pasti meski elastis. Di luar perbatasan itu adalah bangsa-bangsa lain.

Dalam The Discursive Construction of National Identity (Second edition, 2009) Ruth Wodak dkk, memperkenalkan dan menjelaskan konsep homo nationalis yang merujuk kepada homo Austriacus: 'orang Austria', 'tipikal karakter orang Austria', perilaku 'orang Austria', 'mentalitas nasional (Volkscharakter) orang Austria', keragaman budaya 'orang Austria', teritori 'orang Austria', dan fantasi sebagai 'keturunan (asal, nasib, tempat lahir, kampung halaman, tempat tinggal, dan sosialisasi) orang Austria'. Homo nationalis (homo Austriacus) berkaitan erat dengan wacana atau konstruksi narasi kebangsaan secara politik, sosial, dan kultural baik pada masa lalu, sekarang, dan akan datang. Terminologi homo nationalis yang dipakai dalam kasus ini merujuk kepada 'orangorang Indonesia' yang memiliki 'karakter', budaya, wilayah, 'mentalitas nasional', konstruksi narasi kebangsaan dst, (tersendiri) sebagai sebuah bangsa dan negara.

Seperti yang dijelaskan sebelumnya, pewacanaan akan 'bangsa' yang bersatu dan unik pada satu sisi, dan pewacanaan sebagai bangsa yang beranekaragam pada sisi lain selalu diagendakan, dilakukan, dan 'dilestarikan'. Pewacanaan ini semarak dilakukan baik secara formal, katakanlah melalui beragam regulasi yang dibuat oleh negara, maupun secara informal atau budaya dari tangan 
masyarakat luas, seperti kesenian budaya atau lokal. Dalam masa tertentu bahkan pewacanaan 'kebangsaan' ini masuk dalam ranah yang tak terduka atau tak terpikirkan sebelumnya seperti yang diungkapkan Wodak dkk (1999: 150)

Apparently firmly established national and cultural identities have become contested political terrain and have been at the heart of new political struggles.

Melalui analisis wacana, pengkontekstualisasian dan transformasi konsep politik dengan narasi 'kebangsaan' baik melalui ekspresi politik, insteraksi sehari-hari, budaya, serta media massa dapat dibaca lebih kritis dan mendalam. Menurut Wodak dkk (1999: 153) ada banyak hal yang mewacanakan homo nationalis dan atau identitas kebangsaan', seperti; bahasa, sistem tanda, politik, intelektual, media massa, sekolah, militerisasi, bahkan pertandingan olahraga.

Menurut Wodak dkk (2009) analisis wacana kritis berpusat pada komunikasi sehari-hari seperti media, politik, bahasa, dan tidak menutup kemungkinan terjadi pada situasi yang berbeda. Analisis wacana kritis ini berkaitan erat dengan wacana yang dibangun di dalam tulisan dan percakapan sebagai praktisk sosial. Hal ini menerangkan hubungan dialektika antara proses pewacanaan dan situasi, institusi dan struktur sosial, yang selalu terhubung. Wacana terdapat di dalam praktik sosial dan begitu juga praktik sosial terdapat di dalam wacana. Lebih lanjut Wodak dkk (2009: 8) menjelaskan

Through discourses, social actors constitute objects of knowledge, situations and social roles as well as identities and interpersonal relations between different social groups and those who interact with them. Furthermore, discursive acts are socially constitutive in a variety of ways. Firstly, they are largely responsible for the genesis, production and construction of particular social conditions. Secondly, they can con -tribute to the restoration, legitimation or relativisation of a social status quo (ante). Thirdly, discursive acts are employed to maintain and reproduce the status quo. Fourthly, discursive practice may be effective in transforming, dismantling or even destroying the status quo. In view of these social macrofunctions, we distinguish in this book between constructive, perpetuating and/or justifying discursive strategies as well as strategies of transformation and dismantlement or disparagement.

Melalui pewacanaan ini kemudian 'identitas kebangsaan' sebagai homo nationalis tidaklah stabil, tidak abadi, justru kebalikannya menjadi sangat fleksibel, dinamis, dan kadang membingungkan. Hall dan Gay (2003: 4) menegaskan, tepatnya 'identitas' (dalam hal ini 'identitas kebangsaan') dikonstruksi di dalam dan tidak di luar wacana.

We need to understand them as produced in specific historical and institutional sites within specific discursive formations and practices, by specific enunciative strategies. Moreover, they emerge within the play of specific modalities of power, and thus are 
more the product of the marking of difference and exclusion, than they are the sign of an identical, naturally-constituted unity - an 'identity' in its traditional meaning (that is, an all-inclusive sameness, seamless, without internal differentiation).

Pewacanaan homo nationalis ini terfragmen dalam berbagai hal, seperti; kultur masyarakat yang komunal dan kekeluargaan di Indonesia, batasan teritorial atau geografis, warisan leluhur atau budaya, tak ketinggalan keberagaman dalam kesatuan, kehadiran global dan rural, serta perbandingan masa lalu dan masa sekarang -bak Janus, dewa Romawi, yang bermuka dua; depan dan belakang. Fenomena Janus-faced ini tak terelakkan ketika membincangkan bangsa, dalam arti selalu membandingkan capaian-capaian masa lalu dan saat sekarang sebagai proyek untuk melihat pembangunan dan pendefinisian kebangsaan yang selalu berlanjut.

\section{NutriSari Heritage: Hierarki}

\section{Kebudayaan dalam Kebangsaan}

Iklan minuman NutriSari Heritage ini bercerita tentang kekayaan budaya dan alam Indonesia. Iklan ini menampilkan budaya dari lima etnis/suku bangsa di nusantara; Papua dengan tari perang yang berlatar pesisir (pantai) dan kawasan (destinasi wisata) Raja Ampat, Ambon dengan permainan atau tarian Saurekareka yang berlatar pesisir (pantai), Jawa dengan permainan congklak atau congkak yang berlatar pendopo, Bali dengan tari Pendet yang berlatar pura, dan Betawi dengan kuliner Plethok (ramuan minuman khas) Betawi yang berlatar beranda rumah. Kelima budaya etnis/suku yang ditampilkan ini disertai dengan corak khas dari masing-masing budaya, seperti tato (cat tubuh) dari Papua, pakaian adat dari Ambon, Batik dari Jawa, ritual di Bali dengan menjunjung buah dan sayur di kepala, serta kebaya khas Betawi. Tak ketinggalan lagu-lagu daerah dari etnis/suku yang dipilih untuk mengiringi iklan ini.

$$
\text { Penggambaran etnisitas/suku }
$$
bangsa dalam iklan ini jika diposisikan dalam dua binary, seperti mayoritas/ minoritas; 'bersuara/tidak bersuara'; urban/rural; modern/ tradisional dst, sangat terlihat. Iklan ini dibuka oleh seorang anak Papua yang meniup semacam "sangkakala" atau 'genderang' dari cangkang kerang sebagai penanda atau pemberitahuan, pemanggil anggota suku, atau bisa jadi digunakan untuk abaaba sebelum berperang. Visualisasi berikutnya diikuti dengan indahnya alam Raja Ampat sebagai salah satu destinasi wisata tanah air yang kerap disebut-sebut. Alunan musik khas Papua mengiringi 'orang-orang Papua' ini menari dan bernyanyi. Di tengah nyanyian dan tarian ini hadir sepasang muda mudi sebagai tourist atau pengunjung (seperti tangah liburan dan membawa kamera) bagi 'orang-orang Papua' yang menari dan bernyanyi. Sepasang pengunjung ini 
terlihat bahagia, bertepuk tangan, tersenyum, tertawa, terharu karena diajak menari dan bernyanyi. Tak ketinggalan tentunya kehadiran produk minuman NutriSari yang diminum para penari dan tourist, katakanlah sebagai pengakrab dua kebudayaan yang berbeda (modern/tradisional).

Beranjak kepada etnisitas/suku bangsa Ambon. Anak-anak diperlihatkan bermain Saureka-reka, menari, berlarian bersama, ceria, dilengkapi dengan pakaian adat Ambon. Keceriaan yang dibangun bersamaan dengan hadirnya produk minuman ini di tengah mereka. Dua orang pengunjung di atas kembali hadir, bersama dengan Joshua yang memakai pakaian adat dan berposisi juga sebagai tourist. Anak-anak Ambon juga diperlihatkan sebagai anak-anak yang tumbuh dan besar di alam. Mereka masih memainkan permainan tradisional dan memanfaatkan alam untuk persahabatn dan hiburan. Hal ini terlihat dari kekaguman/ekspresi gadis pengunjung/turis terhadap kebaikan gadis-gadis kecil Ambon yang menyisipkan bunga ke telinganya.

Visualisasi iklan beranjak kedalam masyarakat dan budaya Jawa. Iklan ini menyambut penonton dengan seutas senyuman manis gadis kecil berkemben yang tengah bermain congklak/congkak. Sebuah keluarga besar berkumpul di pendopo, mulai dari kakek, ibu, tante, ayah, anak-anak, beserta cucu. Semua anggota keluarga memakai batik, jarik, kebaya, blangkon, kemben, sanggul, dan sebagainya sebagai penanda masyarakat dari budaya Jawa. Permainan tradisional congklak/congkak hadir bagi anak-anak perempuan dan anak laki-laki sebagai penonton. Alunan gamelan juga mengiringi visualisasi ini. Produk NutriSari hadir di pendopo ini sebagai penyatu dan penghangat hubungan dalam keluarga besar. Sebelum scene iklan ini berakhir, seorang gadis kecil berkemben oranye meminta NutriSari kepada mamanya yang ditanggapi oleh anak lakilaki “Kok, jeruk minum jeruk?”, tanggapan ini mengundang senyum dari Joshua sebagai pengunjung. 'Jeruk kok minum jeruk' adalah tagline produk NutriSari. Hanya di scene inilah pelaku iklan berbicara (aktif), sementara di scene lain tidak ditemukan.

Setelah etnisitas Jawa, selanjutnya suku bangsa Bali ditampilkan. Penonton digiring mengikuti arak-arakan beberapa perempuan membawa berbagai jenis buah dan sayur yang sudah disusun sedemikian rupa bersama janur-janur di atas kepala mereka. Joshua dan endorser lain hadir dengan pakaian khas Bali dan kamera tergantung di leher tengah memberi salam kepada para perempuan itu. Sebelum Joshua dan kawan-kawannya belajar menari tari Pendet, Joshua memperkenalkan NutriSari kepada anakanak Bali tersebut. Mereka meminumnya dengan senang, kemudian belajar menari di sekitar pura. Ekspresi-ekspresi keagamaan pun diperlihatkan. 
Terakhir, visualisasi budaya di Betawi. Joshua dan teman-temannya hadir di beranda rumah bersama seorang perempuan berusia lanjut tengah memperlihatkan foro-foro perjalanan mereka. Perbincangan dan keceriaan terlihat dari sana. NutriSari hadir di tengah mereka dalam bentuk kuliner khas minuman Betawi, yakni Plethok Betawi. Scene yang diperlihatkan adalah NutriSari hadir bersama serei dan kulit manis. Iklan ini ditutup dengan ungkapan 'NutriSari, dari alam untuk Indonesia'. Adapun secara keseluruhan narasi iklan ini disampaikan oleh laki-laki dan diselingi lagu-lagu daerah dari etsitasn/suku bangsa yang hadir. Demikian narasinya: "Sejak Tahun 1970 NutriSari selalu memberikan yang terbaik untuk anakanak Indonesia. Kini NutriSari mengkombinasikan buah dan sayuran untuk memenuhi keseimbangan nutrisi tubuh anda. Terinspirasi dari kekayaan kuliner Indonesia, hadir NutriSari Plethok Betawi. NutriSari dari Alam untuk Indonesia".

Pewacanaan homo nationalis dalam iklan ini terlihat dari keberagaman etnisitas/suku bangsa yang dihadirkan (lima etnisitas/suku bangsa), meskipun pilihan-pilihan itu menimbulkan bias. Bias terhadap Jawa dan Bali, bahwa seolah-olah kehadiran dua budaya ini merupakan 'kunci' ketika melihat 'kebangsaan' dari sudut kultur. Jawa digambarkan hangat, komunal, penuh kasih karena kelengkapan keluarga. Bali digambarkan kaya akan keluhuran dan pengabdian kepada Sang Pencipta serta di sana banyak kebaikan, katakanlah kebaikan buah dan sayur, seperti yang dipromosikan oleh NutriSari. Noviani (2012: 47) mengatakan.

From the commercial point of view, Java has been always a big market, where big capitals could flow rapidly. As a political result, however, it produced dictating to the non-Javanese by the Javanese in light of the media's image setting.

Sementara kehadiran Papua dan Ambon dalam iklan ini lebih terkait dengan alam, ketradisionalan, eksotisme, dan 'perlu' ditonton. Pada scene Papua dan Ambon terlihat jelas bagaimana kehadiran Joshua dan teman-temannya sebagai penatap bagi anak-anak Papua dan Ambon serta permainan dan tarian mereka sebagai objek tatapan (tourist gaze). Menurut Noviani (2012: 49): In case they were invisible, they were merely performed as a spectacle, an object to gaze at, which reproduced the dominant ethnic group's attitudes amd ideas toward them.

Pada konteks ini juga terlihat bagaimana pewacanaan modern dan tradisonal dalam 'kebangsaan'. Posisi Papua sebagai yang tradisonal diperlihatkan dari tarian yang mereka lakukan sebagai objek tontonan. Sementara kehadiran pengunjung atau turis memperlihatkan sebuah era kemodernan dimana pengalaman menonton beragam budaya menjadi 
sesuatu yang diangan-angankan, yang tidak atau belum ditemukan pada masyarakat Papua. Seperti yang diungkapkan Boorstin (dalam Odih, 207: 43) For him (Boorstin), the 'traveller' was a member of an elite group of privileged individuals who actively sought authentic cultural experiences in their travels abroad. Pada tataran ini, agaknya, apa yang dikatakan sebagai 'pseudo-events' oleh Boorstin itu terjadi, yaitu kehadiran ritual-ritual dan ekspresi budaya lainnya bertransformasi menjadi semacam 'ceremony' sebagai produk budaya yang mengedepankan 'event' sebagai yang ditonton. 'Makna' tidak lagi menjadi soal ketika ekspresi kultural berpadu dengan era kemodernan dimana pemenuhan akan selera menjadi lebih utama ketimbang 'pemaknaan' kerohanian. Bisa dibaca, kehadiran tari-tarian dari 'orang-orang Papua' dan 'orang-orang Bali' dihadirkan sebatas hanya sebagai 'penyambut' pengunjung sebagai tamu.

The modern American tourist now fills his experince with pseudoevents. He has come to expect both more strangeness and more familiarity tha the world naturally offers, (Boorstin, 1992: 79).

Narasi tentang homo nationalis juga diperlihatkan dengan tanah dan bumi Indonesia yang luas, beragam, indah, hijau, dan konon kaya raya. Raja Ampat, pesisir pantai, pura-pura, atua bahkan pendopo dan beranda rumah merepresentasikan keindonesiaan secara fisik. Bangunan fisik dan geografis ini berbeda dari bangunan dan geografis bangsa lain sehingga 'keindonesiaan' dana homo nationalis dapat dibangun dan diwacanakan. Teritorial dalam konsep 'kebangsaan' menjadi penting. Karena keberdaulatan sebuah 'bangsa' seperti yang dijelaskan Anderson sebelumnya tidak berdaulat secara politis saja, tapi berdaulat secara teritorial juga utama. Pengakuan secara de facto dan pengakuan secara de jure.

Dalam iklan minuman NutriSari Heritage juga diperlihatkan sosiol kultural masyarakat Indonesia. Scene ketika NutriSari hadir di tengah keluarga Jawa memperlihatkan, kecenderungan atau 'karakter' sebagian besar masyarakat ialah berkomunal. Hidup bersama dan berkelompok dengan keluarga besar sudah menjadi 'ciri' budaya masyarakat nusantara. Masyarakat Indonesia mengenal kerja sama atau gotong royong dalam melakukan pekerjaan di lingkungan sosial. Tidak saja berurusan dengan pekerjaan fisik, akan tetapi membagi cerita baik suka maupun duka kepada anggota masyarakat lainnya sudah menjadi 'tipikal' 'orang-orang Indonesia'.

'Family', in this case, does not always refer to a group of person related by blood, marriage, or adoption. In the communal society, people who belong to a certain community and share something in common, one to another, can be considered as family as well, (Noviani, 2012 36-37). 
Slogan iklan NutriSari Heritage 'Dari Alam untuk Indonesia' bisa dibaca dalam dua sisi. Pertama, slogan ini menjelaskan 'Dari Alam' adalah Papua sebagai stereotype, yang juga sebagai pembuka di iklan ini. Papua, provinsi paling timur Indonesia. Papua jauh dari Jakarta sebagai ibu kota negara yang sarat akan kemodernan budaya dan selera. Papua 'identik' dengan alam, bisa jadi alam yang 'liar' seperti tarian perang yang ditampilkan, ataupun alam yang 'friendly dan lucu' seperti anak-anak Papua tersenyum dan bermain-main dengan NutriSari serta para turis. Sementara, 'untuk Indonesia' adalah Betawi. Betawi merupakan 'warga asli' Jakarta. Mereka dekat dengan ibu kota. Dalam iklan ini Betawi digambarkan sebagai masyarakat yang cukup modern, ketika NutriSari hadir dan mengadopsi minuman khas Betawi, Plethok Betawi menjadi lebih 'canggih'.

Kedua, 'Dari Alam untuk Indonesia' bisa dibaca sebagai 'keluhuran' kekayaan dan budaya yang ada di Indonesia. Indonesia yang tropis dan subur, kaya akan beragam tumbuhan; buah dan sayur. NutriSari mengusung kebaikan buah dan sayur untuk menjaga kesegaran, kesehatan, dan penampilan anak-anak serta orang dewasa Indonesia. Ini menjadi momentum bagaimana NutriSari hadir dan peduli pada generasi selanjutnya sebagai pewaris 'bangsa'. NutriSari, seolah-olah, tidak melulu berorientasi pada profit, tapi regenerasi homo nationalis pun menjadi pekerjaan rumah yang penting bagi merek dagang ini. selain itu, kehadiran Bali dengan ritual dan budaya -representasi dari high cultureyang menghadirkan buah dan sayur menjadi semacam metafora dan atau analogi, bahwa ketika mengonsumsi buah dan sayur -tentunya dalam hal ini mengonsumsi NutriSari- yang akan didapatkan tidak hanya kesegaran dan kesehatan fisik, secara psikis pun akan memperoleh 'kedamaian', seperti yang dilakukan oleh 'orang-orang Bali'. Pada tataran ini terlihat pewacanaan homo nationalis dalam produk yang akan dijual erat kaitannya dengan kultur, budaya, bahkan kepercayaan suatu kelompok etnisitas/suku bangsa.

\section{Kesimpulan}

Pewacanaan homo nationalis atau 'kebangsaan' dalam iklan minuman NutriSari Heritage penuh akan konstruksi ‘identitas kebangsaan' sebagai bagian dari suatu 'bangsa' Indonesia. Pewacanaan ini dimulai dengan menghadirkan lima etnisitas/suku bangsa; Papua, Ambon, Jawa, Bali, dan Betawi. Kelima etnisitas/ suku bangsa ini mempertontonkan atribut kebudayaaan; pakaian, kesenian, ritual, permainan tradisional, nyanyian daerah; bentuk geografis (fisik); serta 'karakter' sosial (komunal dan komunitas) sebagai representasi mereka atau afiliasi mereka terhadap salah satu etnisitas/suku bangsa tersebut. Keberagaman ini disatukan oleh satu kata yakni Indonesia. 
Melalui analisis wacana kritis model Ruth Wodak dkk, iklan minuman NutriSari Heritage ini memperlihatkan adanya bias-bias etnisitas/suku bangsa dalam mewacanakan homo nationalis sebagai implikasi karena 'dianggap' mayoritas atau dianggap 'luhung'. Biasbias ini, agaknya, terjadi dikarenakan masih adanya pelabelan tertentu (stereotype) terhadap etnisitas/suku bangsa. Pelabelan ini diproduksi, direproduksi, dijaga, dirawat, dan bahkan dilestarikan dalam berbagai pewacanaan, salah satuanya dalam iklan.

Dalam iklan minuman NutriSari Heritage 'komposisi' dominasi suatu etnisitas/suku bangsa terlihat berbeda. 'Komposisi' dominasi ini tidak berdasarkan banyak sedikit scene etnisitas/suku bangsa tertentu yang diperlihatkan dalam iklan, melainkan sejauh mana etnisitas/suku bangsa tertentu diberi ruang untuk 'berbicara' secara langsung (aktif) ketimbang hanya sebagai objek atau pelaku dalam iklan (pasif). Berdasarkan hal itu, ada tiga etnisitas/suku bangsa yang menempati posisi atau berperan utama dalam iklan ini yaitu, etnisitas/suku bangsa Jawa melalui tagline "Kok, jeruk minum jeruk?" sebagai 'penyambung lidah' NutriSari, etnisitas/suku bangsa Bali melalui kebaikan buah dan sayur yang berkaitan dengan 'keluhuran' budaya dan ritual (spiritual) mereka, serta etnisitas/suku bangsa Betawi sebagai pengejawantah dari etnisitas/suku bangsa yang Indonesia, modern, dan yang berselara lokal namun 'canggih' -ketika dikemas oleh NutriSari. Sementara Papua dan Ambon menempati posisi yang 'sejajar'. Dua etnisitas/suku bangsa ini pasif. Posisi NutriSari bagi dua etnisitas/suku bangsa ini tidak seperti yang digemborkan sebelumnya. Slogan 'Dari Alam untuk Indonesia' menjadi semua, karena kebaikan buah dan sayur justru 'diambil' dari budaya dan ritual 'orang-orang Bali'.

\section{Daftar Pustaka}

Anderson, Benedict. 2008. Imagined Communities:

Komunitas-

Komunitas Terbayang (Cetakan Ketiga). Yogyakarta: Insist Press.

Boorstin, Daniel J. 1992. The Image: A Guide to Pseudo-Events in American. New York: Vintage Book.

Brierley, Sean. 1995. The Advertising Handbook. London dan New York: Routledge.

Davis, Helen. 2004. Understanding Stuart Hall. London, Thousand Oaks, dan New Delhi: SAGE Publications.

Frith, Katherine $\mathrm{T}$ dan Mueller, Barbara. 2003. Advertising and Societies: Global Issues. New York, Washington, D.C./Baltimore, Bern, Frankfurt am Main, Berlin, Brussels, Vienna, dan Oxford: PETER LANG. 
Goldman, Robert. 1992. Reading Ads Socially. London dan New York: Routledge.

Hall, Stuart and Gay, Paul du (eds). 2003. Questions of Cultural Identity. London, Thousand Oaks, dan New Delhi: SAGE Publications.

Moriarty, Sandra dkk. 2012. Advertising \& IMC: Principles \& Practice (Ninth Edition). Boston, Columbus, Indianapolis, dan New York, dll: Prentice Hall.

Noviani, Ratna. 2012. Identity Politics in Indonesia Advertising: Gender, Ethnicity/Race, Class, and Nationality in TV Advertisements during the New Order and the PostNew Order Era. Yogyakarta: Kanisius.

Piller, Ingrid. 2001. "Identity Constructions in Multilingual Advertising". Jurnal Language in Society, Vol. 30, No. 2 (Jun., 2001), pp. 153-186.
Odih, Pamela. 2007. Advertising in Modern and Postmodern Times. London, Thousand Oaks, dan New Delhi: SAGE Publications.

Wodak, Ruth dkk. 2009. The Discursive Construction of National Identity (Second edition). Edinburgh: Edinburgh University Press.

Wodak, Ruth dkk. 1999. "The Discursive Construction of National Identities". Discourse \& Society, Vol 10(2): 149173. London, Thousand Oaks, CA, dan New Delhi: SAGE Publications.

\section{Sumber Internet}

Iklan Minuman Nutrisari Heritage http://www.youtube.com/watch?v= FZXXGKHfwmA diakses 26 Maret 2013.

Iklan Minuman Nutrisari Heritage https://www.facebook.com/NutriSa $\underline{\text { ri?fref=ts }}$ diakses 27 April 2013.

NutriSari

http://www.wikipediaindonesia.co $\underline{m / n u t r i s a r i} \quad$ diakses 27 April 2013. 